\title{
Glutathione Metabolism and the Novel Role of Mitochondrial GSH in Retinal Degeneration
}

\author{
Parameswaran G. Sreekumar ${ }^{1}$, Deborah A. Ferrington ${ }^{2}$ and Ram Kannan $1,3, *$ \\ 1 The Stephen J. Ryan Initiative for Macular Research (RIMR), Doheny Eye Institute, \\ Los Angeles, CA 90033, USA; sparameswaran@doheny.org \\ 2 Department of Ophthalmology and Visual Neurosciences and Stem Cell Institute, University of Minnesota, \\ Minneapolis, MN 55455, USA; ferri013@umn.edu \\ 3 Stein Eye Institute, Geffen School of Medicine, University of California, Los Angeles, CA 90095, USA \\ * Correspondence: rkannan@doheny.org
}

Citation: Sreekumar, P.G.;

Ferrington, D.A.; Kannan, R.

Glutathione Metabolism and the

Novel Role of Mitochondrial GSH in Retinal Degeneration. Antioxidants 2021, 10, 661. https://doi.org/ 10.3390/antiox10050661

Academic Editor: Michele

C. Madigan

Received: 29 March 2021

Accepted: 21 April 2021

Published: 24 April 2021

Publisher's Note: MDPI stays neutral with regard to jurisdictional claims in published maps and institutional affiliations.

Copyright: (c) 2021 by the authors. Licensee MDPI, Basel, Switzerland. This article is an open access article distributed under the terms and conditions of the Creative Commons Attribution (CC BY) license (https:/ / creativecommons.org/licenses/by/ $4.0 /)$.

\begin{abstract}
Glutathione (GSH) is present ubiquitously, and its role as a crucial cellular antioxidant in tissues, including the retina, is well established. GSH's antioxidant function arises from its ability to scavenge reactive oxygen species or to serve as an essential cofactor for GSH S-transferases and peroxidases. This review summarizes the general functions, retinal distribution, disorders linked to GSH deficiency, and the emerging role for mitochondrial GSH (mGSH) in retinal function. Though synthesized only in the cytosol, the presence of GSH in multiple cell organelles suggests the requirement for its active transport across organellar membranes. The localization and distribution of 2-oxoglutarate carrier (OGC) and dicarboxylate carrier (DIC), two recently characterized mitochondrial carrier proteins in RPE and retina, show that these transporters are highly expressed in human retinal pigment epithelium (RPE) cells and retinal layers, and their expression increases with RPE polarity in cultured cells. Depletion of mGSH levels via inhibition of the two transporters resulted in reduced mitochondrial bioenergetic parameters (basal respiration, ATP production, maximal respiration, and spare respiratory capacity) and increased RPE cell death. These results begin to reveal a critical role for mGSH in maintaining RPE bioenergetics and cell health. Thus, augmentation of mGSH pool under GSH-deficient conditions may be a valuable tool in treating retinal disorders, such as age-related macular degeneration and optic neuropathies, whose pathologies have been associated with mitochondrial dysfunction.
\end{abstract}

Keywords: retinal degeneration; mitochondrial GSH; RPE; SLC25A10 (DIC); SLC25A11 (OGC); bioenergetics

\section{Background}

Glutathione (GSH), one of the most abundant non-protein thiols present at millimolar concentrations in mammalian tissues, is involved in a plethora of functions stemming from combating oxidative stress to immune function and fibrogenesis [1-4]. GSH exists in reduced and disulfide-oxidized (GSSG) forms [5]. Under physiological conditions, the reduced GSH is the major form and accounts for $>98 \%$ of total GSH $[5,6]$. About $80-85 \%$ of the cellular GSH is present in the cytosol, and $10-15 \%$ is associated with mitochondria, with a small fraction found in the endoplasmic reticulum (ER) and nucleus [7-10]. In most of these compartments, GSH is typically found in a highly reduced state, but, in the ER, a substantial portion is oxidized, whereas in the cytoplasm the oxidized form is usually on the order of about $1 \%$ of the total or less [10-12].

The requirement for large quantities of GSH is likely due to its role in multiple processes, including protecting proteins during an oxidative stress through the reversible glutathionylation of active thiols. GSH also maintains the reduced form of multiple antioxidant enzymes through the process of redox cycling, which involves repeated reductionoxidation (SH to $\mathrm{SS}$ ) reactions at active site cysteine residues (Figure 1). The main role 
for this antioxidant system is to eliminate harmful peroxides, such as hydrogen peroxide and organic peroxides, via their reduction by GSH peroxidase (GPx), with GSH serving as a cofactor. The oxidized form (GSSG) is predominantly produced by the catalysis of GSH peroxidase (GPx), as well as from the direct reactions of GSH with electrophilic compounds and reactive aldehydes, such as 4-hydroxy-2-nonenal (HNE), catalyzed by GSH S-transferase (GST). GSSG can be recycled back to GSH by either nicotinamide adenine dinucleotide phosphate (NADPH)-dependent GSH reductase (GR) or glutaredoxin (GRX) such that the GSH pool is markedly reduced with low levels of GSSG being present $[13,14]$. Thus, quantifying the ratio of GSSG to GSH is considered as one of the best indicators of cellular oxidative stress.
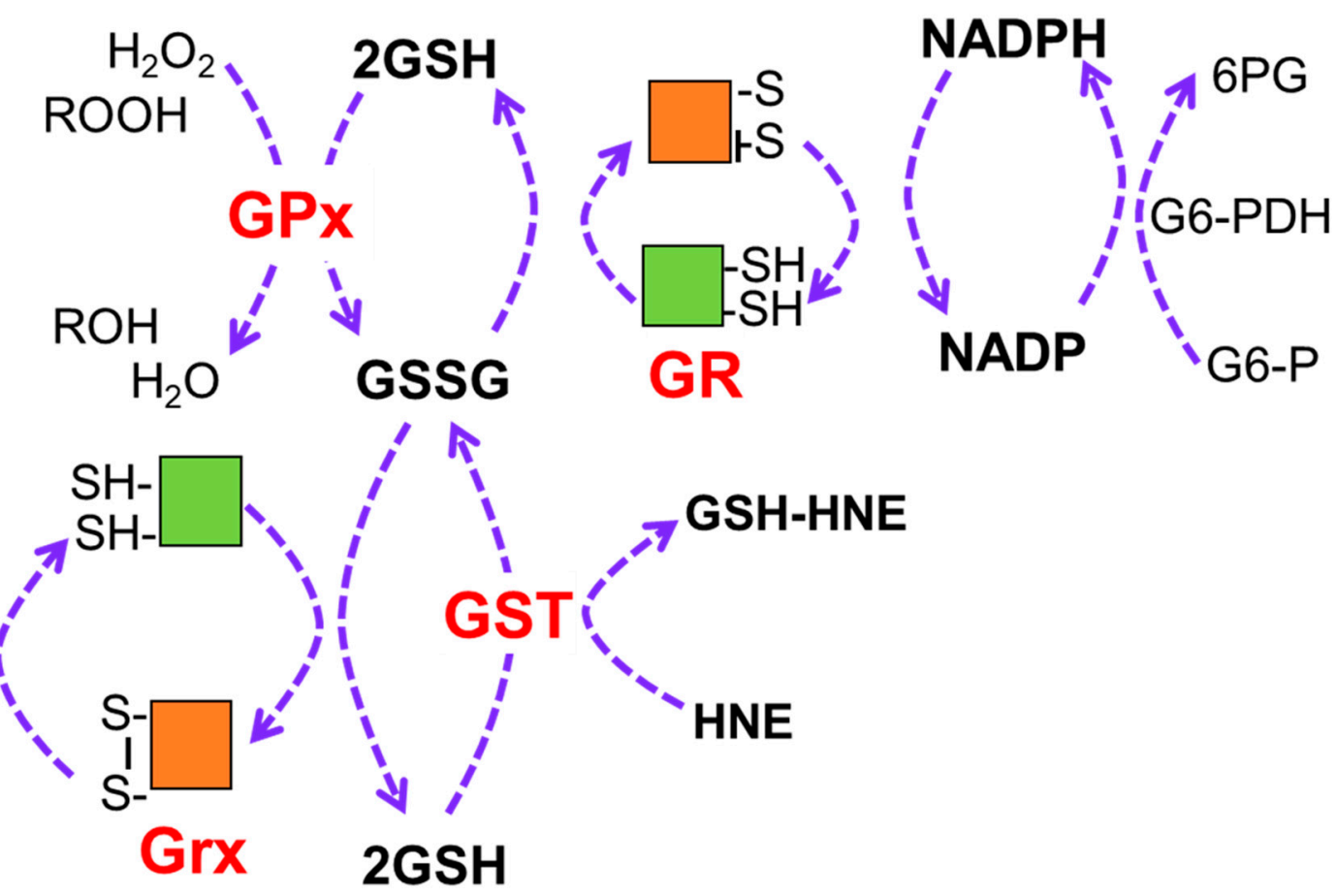

Figure 1. Redox cycling regenerates antioxidants and requires GSH. Antioxidants undergo multiple rounds of reductionoxidation at active site cysteine residues, which are represented by the disulfide (S-S) and SH, respectively. GSH provides the reducing equivalents for these reactions involving the reduction in harmful hydrogen peroxide and organic peroxides $(\mathrm{ROOH})$ by GPx or neutralization of reactive aldehydes, such as HNE, through addition of GSH by GST. GSSG is replenished to GSH by either NADP-dependent GR or Grx. NADPH is produced by reaction with glucose 6-phosphate dehydrogenase. NADPH, nicotinamide adenine dinucleotide phosphate; GSH, reduced glutathione; GSSR, oxidized glutathione; GR, glutathione reductase; GPx, glutathione peroxidase; Grx, glutaredoxin; GST, glutathione S-transferase; G6-PDH, glucose 6-phosphate dehydrogenase.

\section{Glutathione Biosynthesis}

GSH biosynthesis is a multi-step process in which the three precursor amino acids, cysteine, glutamate, and glycine, are combined to form the tripeptide GSH (Figure 2A). GSH is synthesized exclusively in the cytosol by the sequential action of two ATP-dependent enzymes, glutamate-cysteine ligase (GCL) and glutathione synthetase (GS) [15]. The GCL enzyme is composed of a catalytic unit (GCLC) and a modifier subunit (GCLM), which are encoded by different genes [14]. The catalytic unit contains all substrate binding sites, whereas the regulatory unit modulates the affinity of the active subunit for substrates and inhibitors [14]. Genetic elimination of each subunit provides some indication of their relative importance and contribution to cell protection. Mice lacking GCLM demonstrate no outward phenotype but exhibit a marked decrease in GSH and increased sensitivity to toxic insults [16]. Mice lacking GCLC die before birth [17]. GCL catalyzes the first, rate-limiting step of the biosynthetic pathway by which glutamate and cysteine are linked 
to produce $\gamma$-glutamylcysteine in the presence of ATP and Mg2+ or Mn2+ [18]. The last step of the biosynthetic pathway of GSH synthesis is by the addition of glycine to the $\gamma$-glutamylcysteine intermediate catalyzed by GSH synthetase (Figure 2) [14]. GSH can be hydrolyzed to cysteinyl glycine and 5-oxoproline by $\gamma$-glutamyl cyclotransferase activity of cation transport regulator-like protein 1 (CHAC1) $[19,20]$. Glutamate is formed by the breakdown of 5-oxoproline in the presence of 5-oxoprolinase, while cysteinyl glycine is cleaved by respective peptidases to yield cysteine and glycine. These newly liberated amino acids can be reused for the synthesis of GSH [19].

A

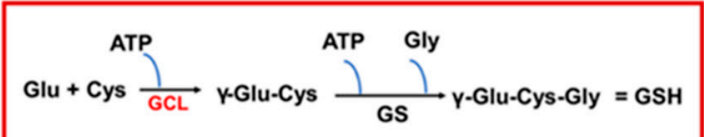

B

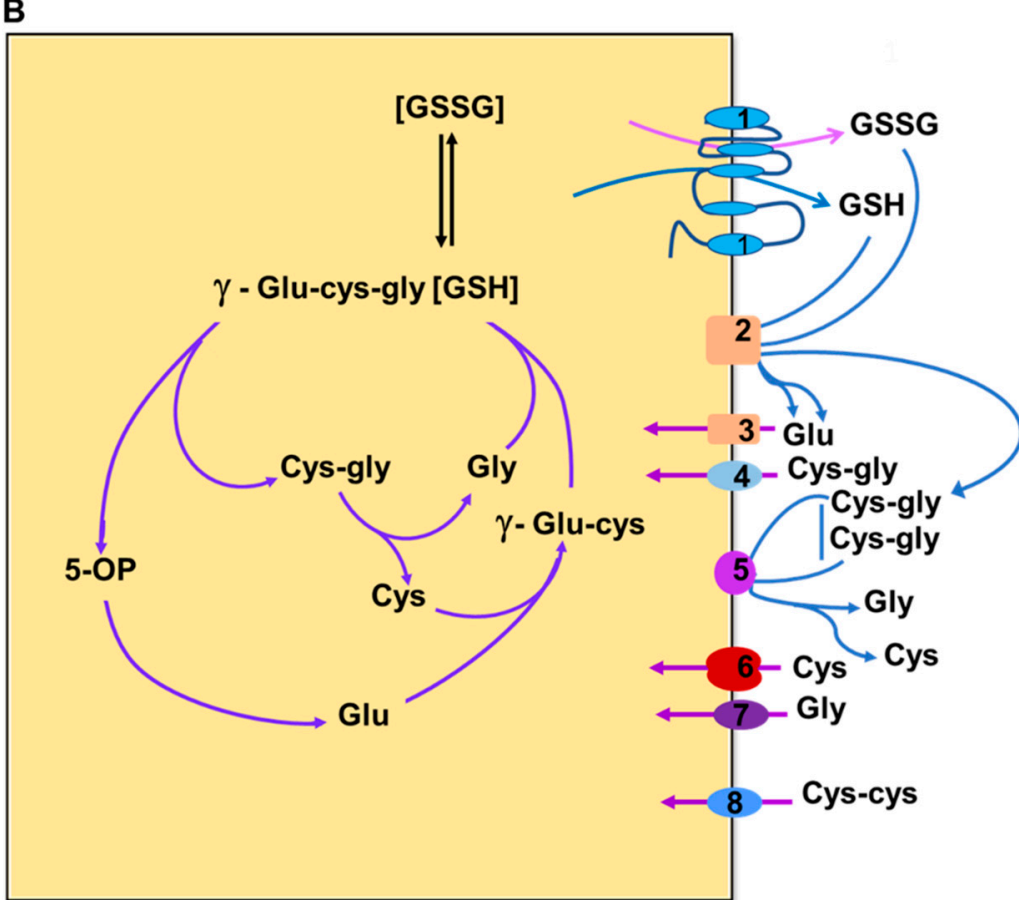

Figure 2. Scheme showing the biosynthesis of GSH (A), and the glutathione cycle and transport of constituent amino acids and related substrates (B). Figure 2B is modified from Bachhawat AK, Yadav S. The glutathione cycle: glutathione metabolism beyond the $\gamma$-glutamyl cycle. IUBMB Life. 2018 July; 70(7):585-592. doi: 10.1002/iub.1756. Epub 2018 Apr 17. PMID: 29667297. Wiley Publishers [19]. GCL—glutamate-cysteine ligase, GS—glutathione synthetase, GSH—glutathione. 5-OP-5-oxoproline. Numbers refer to representative transporters involved. 1-2. MRP family; 3. EAATS family; 4 . Peptide transporters; 5-6. System $\mathrm{Xc}^{-}$and other transporters; 7. Glycine transporter; 8. Disulfide transporter.

\section{Glutathione Function in Cells and Tissues}

As discussed previously, GSH is required for the maintenance and regulation of tissue redox homeostasis. Its multi-faceted functions include contributions to key pathways, such as the regulation of transcription factors involved in redox signaling, metabolism of estrogens, leukotrienes, and prostaglandins, cellular proliferation, apoptosis, and the detoxification of many endogenous compounds and xenobiotics [5,10]. A deficiency of GSH or a major change in the glutathione/glutathione disulfide (GSH/GSSG) ratio renders cells or cellular organelles vulnerable to stress-induced damage. The resulting tissue injury is believed to be associated with the induction and or progression of several neurodegenerative diseases, autoimmune diseases and ocular disorders, such as age-related macular degeneration (AMD), glaucoma, Leber's Hereditary Optic Neuropathy, and diabetic retinopathy [21-27]. The decline in retinal GSH levels in the above conditions is likely dictated by factors, such as the severity of stress and disease, genetics, age, gender, or environmental factors.

In contrast to the neurodegeneration and lower basal GSH levels observed at late stages of disease, there is evidence that cells experiencing earlier disease have increased 
protection from oxidative stress through utilization of GSH. For example, cell protection from hydrogen peroxide, which is directly detoxified by GSH or other antioxidants involved in redox cycling (Figure 3), was observed in primary RPE cultures from AMD donors [21]. It is important to note that these donors were at early stages of AMD, prior to vision loss. While a dose-dependent decrease in cell survival was observed in RPE from donors with and without AMD, the RPE from AMD donors were more resistant to peroxide-induced death (Figure 3A). Additional experiments that reported RPE from AMD donors were also more resistant to peroxide-induced reductions in both mitochondrial and glycolytic function. The resistance to oxidative damage by AMD RPE was attributed to their increased utilization of GSH after exposure to peroxide. This idea is supported by measurement of GSH content after exposure to increasing doses of peroxide, which showed that GSH depletion was significantly greater in cells from AMD donors (Figure 3B). While the mechanism responsible for the coordinate reduction in GSH and resistance to cell death in AMD RPE donors was not explored, GSH protection could occur by eliminating peroxide via by GSH peroxidase (Figure 1) or through the reversible glutathionylation of critical cysteine residues. These results provide additional evidence of the importance of GSH in protecting the cell from oxidative damage and cell death.
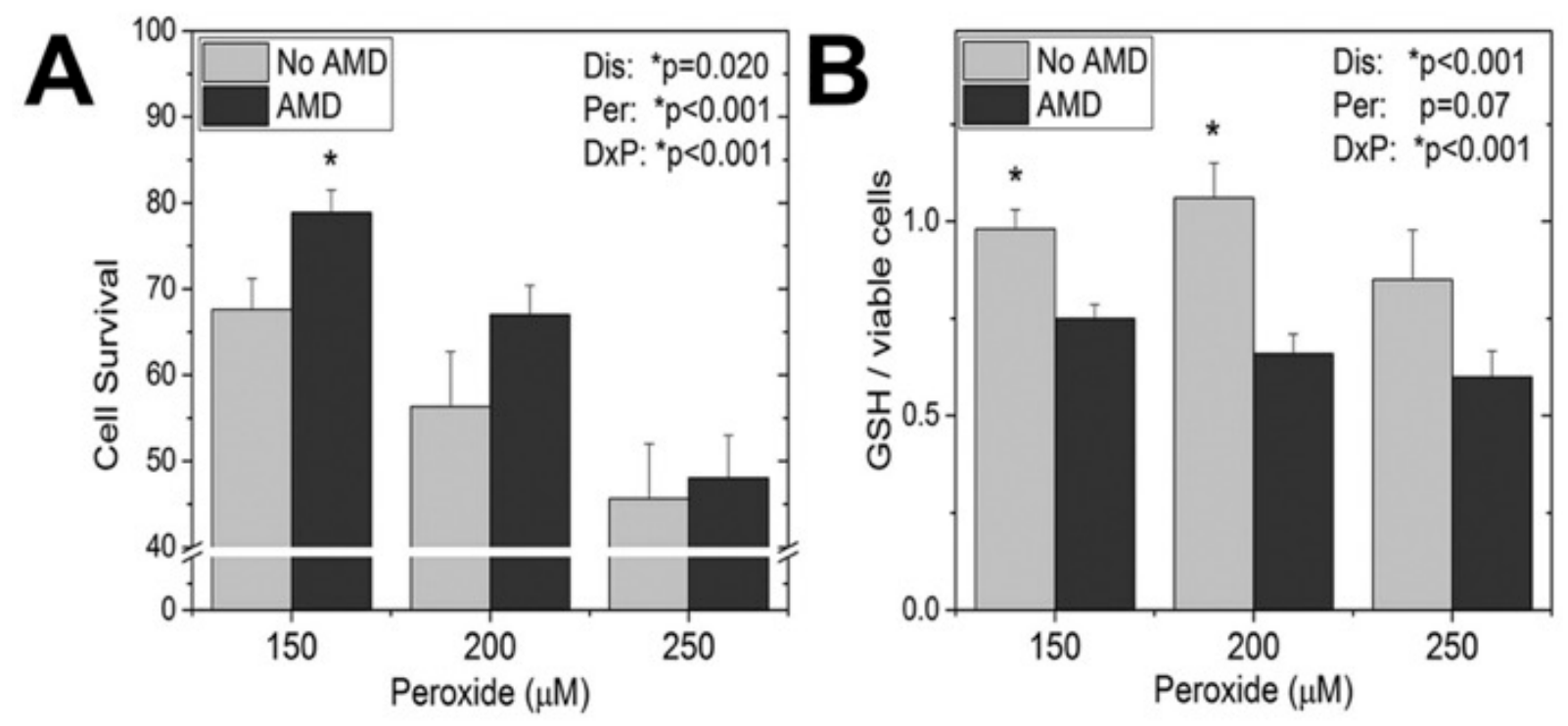

Figure 3. Effect of oxidative stress on cell survival (A) and GSH levels (B) in RPE isolated from AMD donors and agematched controls (no AMD). Results were measured $24 \mathrm{~h}$ after RPEs were exposed to different doses of hydrogen peroxide. Modified from Redox Biol. 2017; 13:255-265, Ferrington et al. [21]. Copyright (2021), with permission obtained from Elsevier. ${ }^{*} p<0.05$ as determined by 2-way ANOVA and Tukey's post-hoc test. Results from 2-way ANOVA for disease (Dis), peroxide dose (Per), and their interaction (DxP) are shown on the graphs.

A link between deficiency of GSH and pathological changes associated with epithelialmesenchymal transition (EMT) has been shown mainly in studies with cultured cells [28] EMT process has been demonstrated to play a pivotal role in posterior capsular opacification, a postoperative complication of cataract surgery that occurs due to the proliferation, migration, and transformation of remnant lens epithelial cells [29]. Data from the lens-conditional gamma glutamyl-cysteine ligase subunit (GCLC) knockout (KO) mice (LEGSKO mice) showed the deficiency of GSH promoted EMT via the regulation of the Wnt/catenin pathway in lens epithelial cells [30]. EMT has been reported in intraocular fibrotic disorders, such as proliferative vitreoretinopathy [31,32], where migration of RPE into the vitreous has been observed. Given the widely accepted fact that GSH is involved in several ocular diseases, there is considerable interest in formulating therapies focused on regulating GSH levels, especially mitochondrial GSH (mGSH), which could help to modulate disease risk or progression. 


\section{GSH Distribution in the Retina and RPE in Health and Disease}

The retina has one of the highest oxidative metabolic rates per tissue weight $[33,34]$. Increased oxygen flux, continuous exposure to light, and the availability of easily oxidized polyunsaturated fatty acids promote an environment in the retina that is highly susceptible to oxidation. Therefore, an effective antioxidant system is required to protect retinal tissues from the continuous exposure to reactive oxygen species. The presence of the GSH antioxidant system, including the enzymes involved in GSH metabolism and regeneration (Figure 1), has been well documented in retinal cells, such as photoreceptor outer segments, Müller glial cells, RPE cells, retinal astrocytes [1,35-39]. Data from gene and protein expression are consistent with GSH as one of the most prominent antioxidants in retina and RPE cells $[38,40]$.

GSH distribution and content demonstrates cell-type-dependent, as well as stressdependent, properties. In a study examining the effect of ischemia on the cellular distribution of GSH in the rat retina, a redistribution of GSH from Müller glia and astrocytes to neuronal cells was demonstrated by the gradual increase in staining [41]. In normal monkey retina, GSH labeling was found primarily confined to Müller cells and horizontal cell bodies through retinal neurons. However, in the glaucomatous retinas, Müller cell immunoreactivity for GSH was always greater [42]. Immunogold labeling studies in adult pig retina showed the strongest immunolabeling for GSH in the RPE cells and in choroid fibroblasts. Intermediate densities of gold particles were recorded in Müller cells and photoreceptor inner segments [40]. However, subcellular localization revealed immunoreactivity was enriched in the mitochondria relative to the cytoplasmic matrix [40]. Intraperitoneal injection of 1-buthionine sulfoximine (BSO), an irreversible inhibitor of GCL, in mice caused GSH depletion and increased cell death. BSO treatment first affected the cells of the inner nuclear layer before cells in other layers of the retina [43]. This was attributed to the oxidation of GSH in some layers and the activation of GSH synthesis in other retinal layers. While the diseases associated with the deficiency of endogenous antioxidants are far too many to list, information on the link between GSH and retinal diseases for select publications directly relevant to this review is presented in Table 1.

Table 1. Regulation of GSH in retinal diseases.

\begin{tabular}{|c|c|c|c|c|}
\hline Pathology & & Levels & Model (s) Studied & Ref \\
\hline Wolfram syndrome 1 (WS) & $\downarrow$ & Total GSH & Wfs $1-/-$ mice & [44] \\
\hline Wolfram syndrome & 4 & $\begin{array}{c}\text { GSSG/GSH and } \\
\mathrm{NAD}(+) / \mathrm{NADH} \text { ratios }\end{array}$ & Miner1 $(-/-)$ mice & [45] \\
\hline $\begin{array}{l}\text { Age-related macular } \\
\text { degeneration (AMD) }\end{array}$ & $\downarrow$ & Plasma Total GSH & Human AMD patients & [46] \\
\hline Exudative AMD & $\downarrow$ & Plasma Total GSH & Human ex-AMD patients & [47] \\
\hline Exudative AMD & $\downarrow$ & Plasma Total GSH & Human ex-AMD patients & [48] \\
\hline AMD & $\downarrow$ & Mitochondrial GSH & $\begin{array}{l}\text { hRPE cells and RPE from alpha } \\
\text { Cry KO mice }\end{array}$ & [49] \\
\hline AMD & $\checkmark$ & Cellular GSH & $\begin{array}{l}\text { ARPE-19 cells treated with BSO or } \\
\text { erastin }\end{array}$ & [50] \\
\hline AMD & 4 & $\begin{array}{l}\text { Oxidized glutathione } \\
\text { (GSSG) in plasma }\end{array}$ & Human early AMD patients & [24] \\
\hline Dry AMD & $\downarrow$ & Total GSH & $\begin{array}{l}\text { RPE cells from AMD donors } \\
\text { subjected to } \mathrm{H} 2 \mathrm{O} 2\end{array}$ & [51] \\
\hline
\end{tabular}


Table 1. Cont.

\begin{tabular}{|c|c|c|c|c|}
\hline Pathology & & Levels & Model (s) Studied & Ref \\
\hline AMD & & $\begin{array}{l}\text { (precursor for GSH) } \\
\text { respiration and ATP } \\
\text { uction }\end{array}$ & RPE cells from AMD donors & [52] \\
\hline AMD & $\downarrow$ & $\begin{array}{l}\text { Cellular GSH, ATP } \\
\text { production, and basal } \\
\text { respiration }\end{array}$ & $\begin{array}{c}\text { RPE from AMD donors and } \\
\text { non-AMD with and without } \mathrm{H} 2 \mathrm{O} 2 \\
\text { treatment }\end{array}$ & [21] \\
\hline AMD & $\downarrow$ & GSH:GSSG ratio & $\begin{array}{l}\text { ARPE19 cells subjected to } \mathrm{H} 2 \mathrm{O} 2 \\
\text { exposure }\end{array}$ & [53] \\
\hline AMD & $\hat{1}$ & Ocular GSH & $\begin{array}{l}\text { ARPE } 19 \text { incubated with and rats } \\
\text { fed N-acetyl-L-cysteine ethyl ester } \\
\text { or N-acetyl-L-cysteine }\end{array}$ & [54] \\
\hline AMD & $\downarrow$ & GSH & LAMP2-silenced ARPE-19 cells. & [55] \\
\hline AMD & $\downarrow$ & GSH & $\begin{array}{l}\text { ARPE19 cells stressed with } \\
\text { tert-Butyl hydroperoxide }\end{array}$ & [56] \\
\hline AMD & $\downarrow$ & GSH & $\begin{array}{l}\text { ARPE-19/primary human RPE } \\
\text { cells were exposed to cigarette } \\
\text { smoke extract or hydroquinone }\end{array}$ & [57] \\
\hline AMD & $\downarrow$ & GSH & ARPE-19 cells treated with $\mathrm{H} 2 \mathrm{O} 2$ & [58] \\
\hline AMD & $\downarrow$ & Cellular GSH & $\begin{array}{l}\text { ARPE-19 cells treated with } \\
\text { hydroquinone }\end{array}$ & [59] \\
\hline AMD & $\uparrow$ & Cellular and mitoGSH & $\begin{array}{l}\text { ARPE-19 treated with NAC } \\
\text { prodrugs }\end{array}$ & [59] \\
\hline AMD & $\downarrow$ & GSH & ARPE-19 cells treated with $\mathrm{H} 2 \mathrm{O} 2$ & {$[60]$} \\
\hline Diabetic retinopathy & $\downarrow$ & MitoGSH & Streptozotocin (STZ) diabetic mice & [61] \\
\hline Diabetic retinopathy & $\downarrow$ & Retinal GSH & STZ-injected Nrf2-/ - mice & [62] \\
\hline Diabetic retinopathy & $\downarrow$ & GSH & STZ rats & [63] \\
\hline Glaucoma & $\downarrow$ & Plasma GSH levels & Human glaucoma patients & [64] \\
\hline Glaucoma & $\hat{1}$ & GSSG levels & $\begin{array}{l}\text { Human peripheral blood } \\
\text { mononuclear cells }\end{array}$ & [65] \\
\hline Glaucoma & $\downarrow$ & Plasma GSH & Human blood & [22] \\
\hline Retinitis pigmentosa & $\hat{1}$ & Increased GSH & $\begin{array}{l}\mathrm{rd} 1(+/+) \text { and } \mathrm{rd} 10(+/+) \text { mice } \\
\text { treated with NAC }\end{array}$ & [66] \\
\hline Retinitis pigmentosa & $\hat{1}$ & GSSG level & rd10 mouse model & [67] \\
\hline
\end{tabular}

\section{Cellular Plasma Membrane Transport of GSH}

The multiple functions of GSH emphasize the absolute necessity for maintaining adequate GSH pools throughout the cell and its organelles. Considering the properties of GSH, such as the size (307 Da) and net negative charge, GSH transport requires carrier proteins to cross membranes to reach its many targets. Thus, the two main mechanisms for maintaining GSH pools in mammalian cells is GSH uptake via specific transporters and the other through the uptake of amino acids for de novo synthesis of GSH (Figure 2) $[5,68,69]$. The transport of GSH across the plasma membrane is controlled by a switch mechanism 
of the open/closed configuration of the GSH transporters. This transport is uniport and cells generally efflux GSH rather than import as cellular GSH levels are higher than in the intracellular medium. These GSH transporters in the plasma membrane have been known for many decades, and include early reports on the biochemical characterization of GSH transport across the plasma membrane [69-71].

The first identified GSH transporter was the multidrug resistance-associated proteins (MRP), a sub-class of the ATP-Binding Cassette (ABC) transporter superfamily. The MRP family of transporters are found on the plasma membranes of many cells including RPE cells [1]. Furthermore, eight other members of this family (MRP2-9) have been discovered, each with evidence to support GSH conjugates, and other GSH species, as substrates [5]. The MRP transporters are demonstrated as cotransporters of organic anions $(\mathrm{OA}-)$ and GSH [5,72], GSH-conjugated xenobiotics (GS-XN), and GSH-conjugated metabolites. This efflux offers drug resistance to tumor cells and can protect normal cells from toxic insults. MRP1 functions as a GSH-conjugate transporter not only at the plasma membrane but also in intracellular secretory vesicles [73]. Screening of GSH/GSSG efflux transporters revealed MRP1, MRP2, MRP3, MRP4, MRP5, MRP6, and MRP7 are present at the transcript level in the RPE cells among which MRP1 was the most abundant [1]. MRP1 was localized to the plasma membrane, and inhibition of MRP1 markedly decreased GSH efflux [1]. GSH efflux was significantly higher in MRP1-overexpressing RPE cells, which also contained lower levels of cellular GSH and GSSG [1]. However, these efflux pumps had broad substrate specificity and low affinity for GSH and, despite displaying the capacity for GSH transport, appeared to be primarily required for the efflux of GSH conjugates (for example, nitrolinoleic acid), rather than GSH [5].

\section{Mitochondrial GSH and Its Critical Role}

Although they lack the synthetic machinery, multiple organelles, including the nucleus, endoplasmic reticulum, and mitochondria, have their own GSH pool, with reduced GSH to oxidized GSSG that vary between the organelle [74]. In the mitochondria, GSH mainly occurs in a reduced form [75]. This GSH pool allows the mitochondria to resist oxidant insults and to neutralize the superoxide that is generated during the production of ATP as a result of the direct transfer of electrons to molecular oxygen [76,77]. The presence of an effective antioxidant system led by GSH is especially critical when considering that the steady state concentration of superoxide is estimated to be 5-10 fold greater in the mitochondrial matrix than in the cytosol [76].

Emerging studies indicate a pivotal role of mitochondria in initiating multiple signals in response to metabolic and genetic stress that affects nuclear gene expression, causing changes in cell function [77]. mGSH plays a crucial role in the mitochondria, some of which includes its role as an antioxidant, as a detoxifying agent of xenobiotics, a stabilizer of mitochondrial DNA, as a cofactor for Fe-S cluster synthesis [14]. GSH is also a redox regulator of electron transport chain (ETC) proteins that perform oxidative phosphorylation, a process involving the sequential transfer of electrons between the five ETC protein complexes embedded in the inner mitochondrial membrane (IMM) [78,79]. Regulation of these ETC proteins suggest a possible link between mitochondrial metabolism and redox homeostasis through $\mathrm{mGSH}$ status [80]. mGSH depletion significantly decreased mitochondrial basal respiration and ATP production, and the reserve capacity in human RPE cells suggests an oxidative stress-dependent mechanism [81]. Supporting findings have been reported in previous studies with other cell types showing the dependence of mitochondrial function and respiration on mGSH levels [82]. ETC protein expression data suggested that ETC complex II was one of the main target sites where 2-oxoglutarate carrier (OGC) and dicarboxylate carrier (DIC) inhibitors (see below) executed their potential inhibitory effect on the respiratory chain. Treatment of RPE cells with phenyl succinate (PSan inhibitor of OGC) or butylmalonate (BM-an inhibitor of DIC) caused a disruption of complex II. It has been demonstrated that acute oxidative stress to the mitochondria caused 
significant vulnerability to complex I in rat hepatocytes [80]. However, no significant change was noticed in the respiratory chain complex $\mathrm{V}$.

\section{Mitochondrial Import and Export of GSH}

As mentioned earlier, mitochondria are extremely sensitive to the damaging effects of free radicals. Therefore, these organelles are enriched with an array of free radical scavenging systems. Of specific note, the mitochondrial GSH pool is a critical antioxidant reserve that is transported entirely from the cytosolic pool via facilitated transport. As GSH has a net negative charge at physiological $\mathrm{pH}$, the high concentration of $\mathrm{mGSH}$ suggests the presence of specific transport systems that work against an electrochemical gradient [8385]. The concentration of GSH in mitochondria is similar to that of cytosol (10-14 mM). As ubiquitous, semi-autonomous cellular organelles, mitochondria are separated from the cytoplasm by a double membrane, the outer and IMM. Therefore, the membranes of the mitochondria must harbor transporters or channels that facilitate GSH transport. The mechanism of GSH transport across the outer membrane (OMM) appears to be relatively uncomplicated because the porins allow molecules smaller than $\sim 5 \mathrm{kDa}$ to diffuse from the intermembrane space (IMS) across the outer mitochondrial membrane to the cytosol, including small proteins and GSH. However, further evidence is needed to determine whether this is the case for both GSH and GSSG [86]. Moreover, although GSH can cross the OMM, its transport into the mitochondrial matrix cannot be explained by simple diffusion. Of note, the IMM and OMM of the mitochondrion differ strongly with respect to the protein and lipid composition $[75,87]$ and permeability as the IMM is impermeable to several solutes and molecules, including GSH. Therefore, mGSH is imported from the cytosolic by the activity of specific carriers [83]. While the transport of mGSH is not fully understood, evidence from reconstitution assays in proteoliposomes testing for substrate specificity, kinetics, dependence on membrane potential, and sensitivity to carrier-selective inhibitors identified two potential members of the mitochondrial carrier family (SLC25), the mitochondrial dicarboxylate carrier (DIC; SLC25A10) and the 2-oxoglutarate carrier (OGC; SLC25A11) [88-92] as mitochondrial GSH transporters. OGC imports cytosolic GSH into mitochondria in exchange for 2-oxoglutarate (2-OGC) and other dicarboxylates (usually malate). DIC mediates electroneutral exchange of dicarboxylates or GSH for inorganic phosphate [93,94]. OGC was shown to have overlapping substrate specificities with some other mitochondrial carriers, but none of these carriers shared the complete group of OGC substrates (2-oxoglutarate, oxaloacetate, malonate, malate). The citrate carrier (CIC) overlaps with OGC by transporting the substrates malate and malonate [95]. The role of OGC as the porphyrin transporter, which is required for the mitochondrial import of the precursor porphyrin for final conversion to heme, has also been reported [96].

The Kannan laboratory was the first to report the expression, localization, and the putative role of mGSH carriers in cell death and mitochondrial bioenergetics in early passage human RPE cells [81,97]. Pharmacologic inhibition of OGC or DIC caused a significant mGSH depletion and increased cell death in RPE cells [97]. As presented in Figure 4, OGC and DIC carrier protein expression was significantly increased in polarized RPE cells, which mimic features of the native RPE monolayer, including apical localization of $\mathrm{Na}, \mathrm{K}-\mathrm{ATPase}$ and basolateral localization of bestrophin with hexagonal morphology, pigmentation and transepithelial resistance [98]. However, the implication of these findings of elevated mGSH levels in polarized RPE monolayers remains to be evaluated. It was further shown that inhibition of DIC and OGC resulted in mGSH depletion, which significantly decreased mitochondrial respiration, ATP production, and altered ETC protein expression in RPE cells [81]. This was also the case under conditions of silencing OGC siRNA. In addition, chemical inhibition of DIC and OGC caused a tight junction break and a significant drop in TER in polarized human RPE monolayers. 


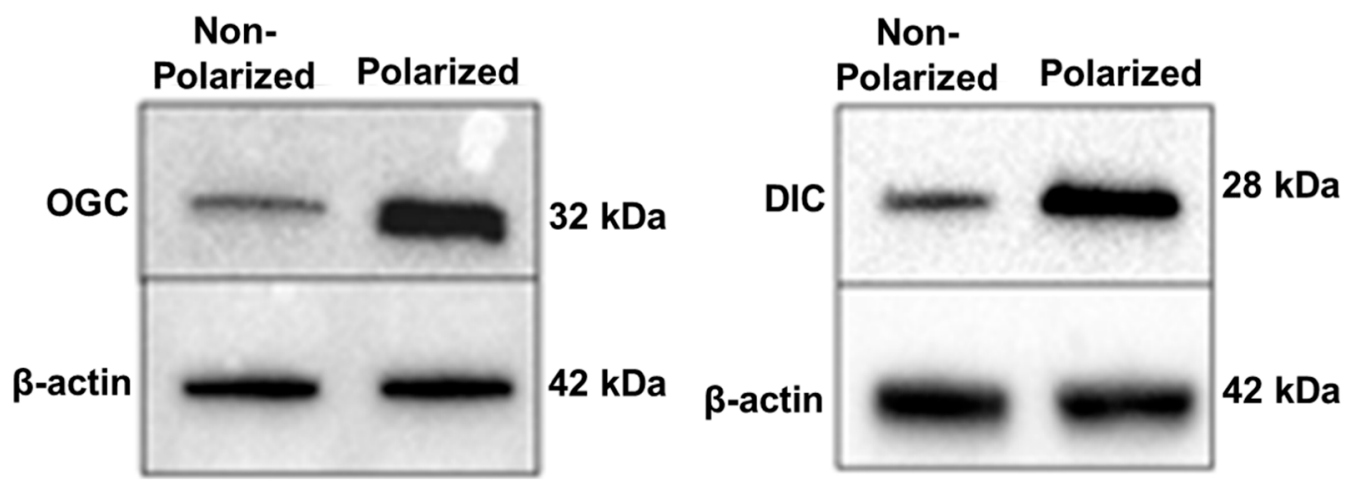

Figure 4. Polarity upregulates mitochondrial carrier proteins, OGC and DIC, in primary human RPE cells. Polarized RPE cultures had an average TER of $380 \pm 60 \Omega \cdot \mathrm{cm}^{2}$ (reproduced from [97] and is licensed under a Creative Commons Attribution-NonCommercial-NoDerivatives 4.0 International License).

While data support a role for OGC and DIC in importing GSH into the mitochondria, these two carriers together accounted for only an apparent $45-50 \%$ of the total GSH uptake in liver mitochondria and 70-80\% in kidney mitochondria [99]. A similar observation was also reported in RPE cells in which inhibition of OGC and DIC did not completely block mitochondrial GSH import [97]. This implies the existence of other putative mGSH carriers that are still undescribed. A potential candidate is the uncoupling protein 2 (UCP2), which was recently shown to participate in the transport of mGSH. However, the mechanism remains unclear [100].

The regulation of these mitochondrial transporters is an active area of research. Initial studies suggest that $\mathrm{Bcl}-2$ protein as a potential regulator of $\mathrm{mGSH}$ transport by regulating the affinity of OGC for GSH [91]. The coordinated interaction between Bcl-2 and OGC seems to increase the mGSH pool and it has been shown that neuronal cells overexpressing OGC have an increased expression of $\mathrm{Bcl}-2$ protein, an effect that was presumably dependent on the mGSH increase [101]. Therefore, functions attributed to Bcl-2, such as antiapoptotic and potential antioxidant properties, could in part depend on its ability to regulate the mGSH transport and status.

While most of the characterization of mGSH carrier proteins centered around RPE, it remains to be seen whether these transporters have a role in other retinal cell types. Our recent work reveals that in addition to expression in RPE/choroid, OGC and DIC are also found in the inner nuclear layer of the mouse retina (Figure 5A,B). A recent study of the transcriptional profiles from 453 human donor retinas reported the expression of these two mitochondrial GSH carriers (SLC25A10 and SLC25A11), thereby corroborating the findings in murine retina [102]. Taken together, the presence of OGC and DIC in the retina suggests they may contribute to mitochondrial health in photoreceptors other cells of the neural retina, though additional supportive evidence will be necessary to confirm this postulation [97]. In this context, the few reports of OGC or DIC knockout mice associated with the cancer field begin to shed light on the relative importance of each protein. OGC knockout mice show lethality between embryonic day 10.5 and 14.5, thereby implying that OGC is required for embryonic development [103]. On the other hand, DIC gene knockdown significantly altered NADPH production and cell proliferation, and it was proposed that it could be a novel target in anti-cancer strategies [104]. The phenotype and functional consequences for the retina following genetic ablation of the two GSH carrier proteins are an area for further investigation. In addition, the mechanisms underlying the regulation of OGC and DIC in retinal diseases remain to be explored. 
A

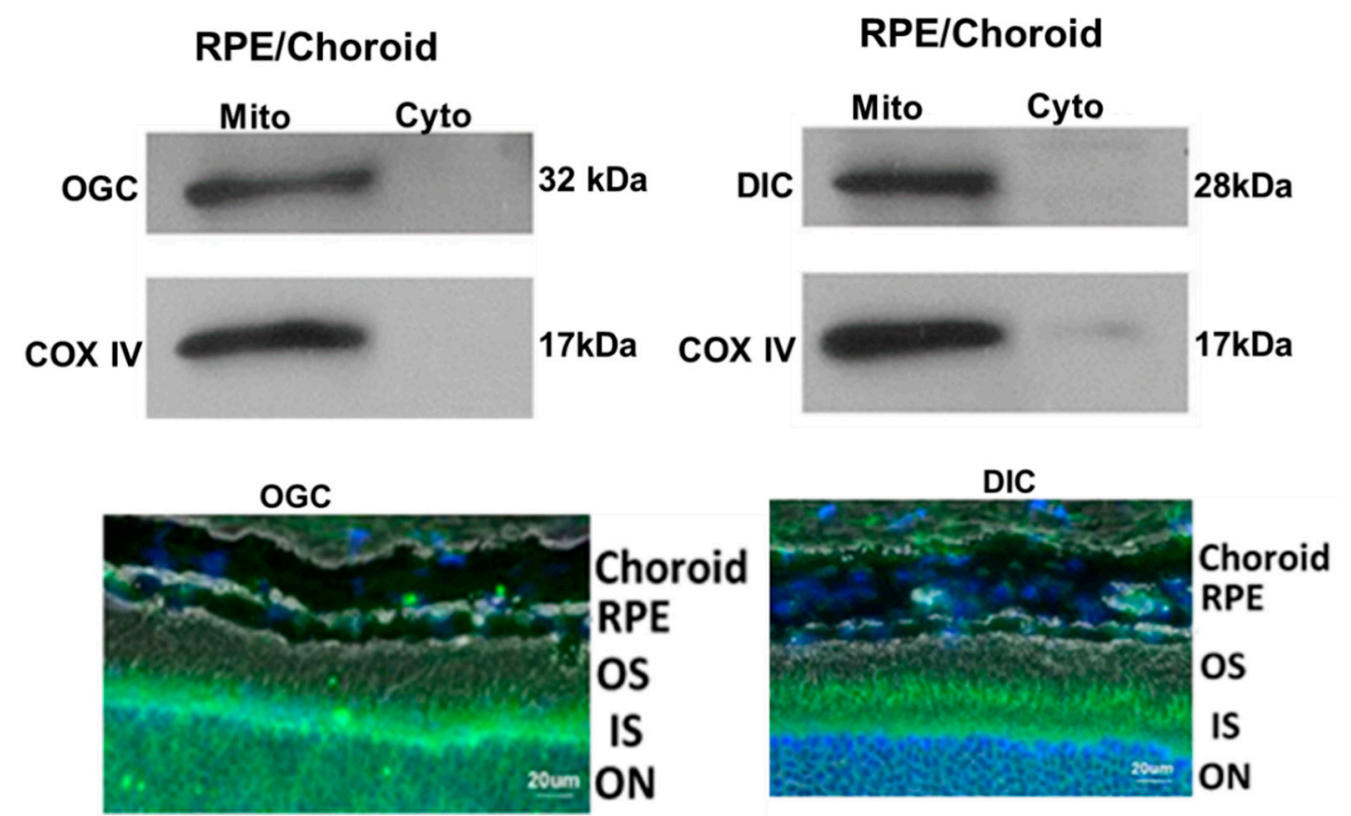

Figure 5. Expression of mGSH carrier proteins in mouse RPE/Choroid (A) and whole retina (B). Mitochondria was isolated as described earlier [97], and the specificity of expression in mitochondria is illustrated with COX IV as a mitochondria specific marker in A. Immunofluorescence staining of OGC (green) and DIC (green) in retinal layers is shown in B. Mito: mitochondria, Cyto: cytosol, COX IV: cytochrome c oxidase subunit 4, Reproduced from [97] and is licensed under a Creative Commons Attribution-NonCommercial-NoDerivatives 4.0 International License. Blue: nuclear stain, DAPI. OS—outer segment, IS—inner segment, ON-outer nuclear layer.

\section{Mitochondrial GSH and Regulation of Cellular Respiration}

Mitochondria in mammalian cells generate most of the cellular energy via oxidative phosphorylation (OXPHOS). Mitochondria are also involved in several other cellular functions, such as $\mathrm{Ca}^{2+}$ homeostasis, heme biosynthesis, nutrient metabolism, steroid hormone biosynthesis, integration of metabolic and signaling pathways for cell death and autophagy $[84,105]$. Previous work has shown that oxidative stress reduced cellular GSH and altered mitochondrial bioenergetic parameters, such as basal respiration, ATP production, maximum respiration, and proton leak in RPE cells [106]. Recently, the Kannan laboratory selectively inhibited mitochondrial GSH using inhibitors of GSH transporters and studied cellular respiration. Studies were conducted on the effect of mGSH depletion on mitochondrial respiratory parameters following pharmacological inhibition of DIC and OGC or silencing of OGC expression, which reduced mGSH pool by 60-70\% [81]. Inhibition of OGC and DIC resulted in a remarkable decrease in basal respiration, maximal $\mathrm{O} 2$ consumption, and respiratory reserve capacity, an indicator of cellular bioenergetic resiliency (Figure 6). Dysregulation of ETC proteins was also observed with mitochondrial GSH inhibition. More in-depth studies will be valuable to establish a definitive role of GSH-dependent mitochondrial respiratory functions in RPE. 
A

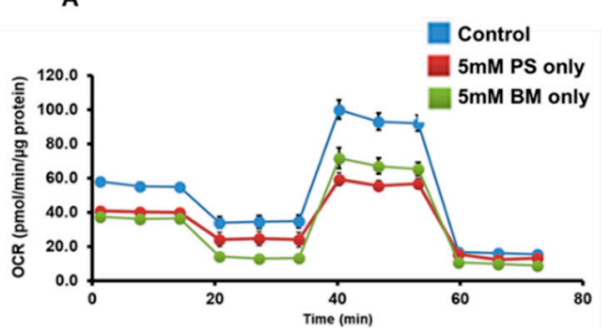

D

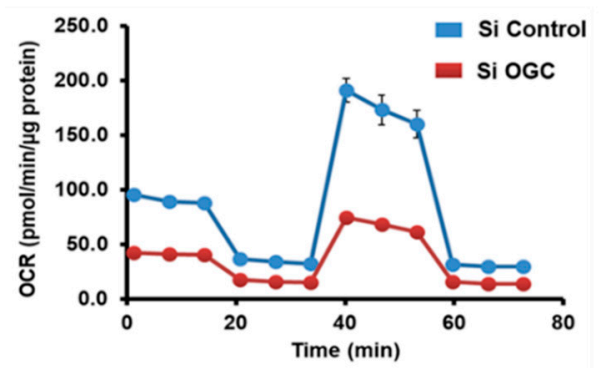

B. Basal Respiration

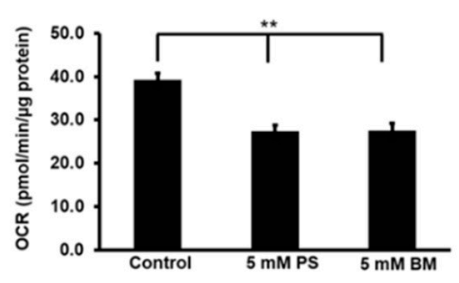

E. Basal Respiration

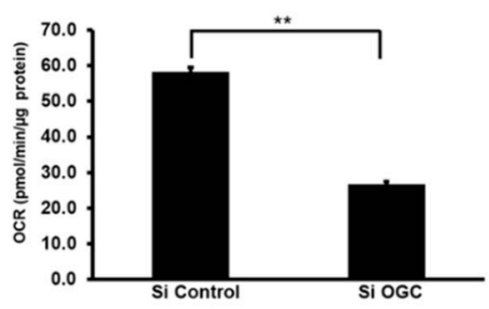

C. Maximal Respiration

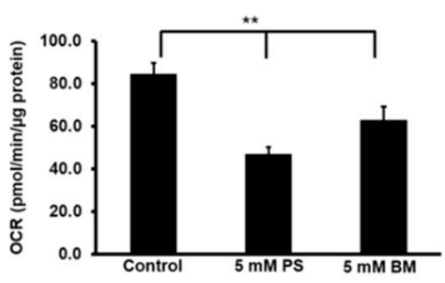

F. Maximal Respiration

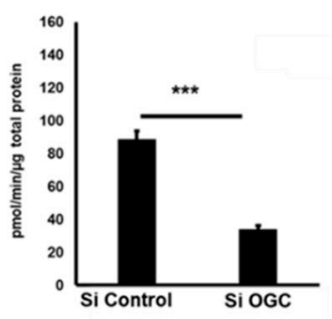

Figure 6. Chemical inhibition of OGC and DIC with PS and BM decreased mitochondrial bioenergetics in RPE (A-C). Silencing OGC caused a significant decrease in respiratory parameters (D-F). (Modified from Sreekumar et al. [81] and is licensed under a Creative Commons Attribution-NonCommercial-NoDerivatives 4.0 International License). ${ }^{* *} p<0.1$ $* * * p<0.01$.

The decrease in mGSH also modulated known components of the mitochondrial biogenesis machinery [81]. A candid experimental evidence for impaired mitochondrial biogenesis in oxidative stress-induced RPE includes a remarkable reduction in mtDNA copy number and decrease in mitochondrial transcription factor A (mtTFA) expression [106]. mtTFA binds mitochondrial DNA and regulates mitochondrial transcription initiation, mtDNA copy number, packaging of mitochondrial DNA, and mitochondrial biogenesis $[107,108]$. However, additional in-depth studies are required using multiple biogenesis markers to assess the contribution of mGSH carriers to mitochondrial function.

\section{Conclusions}

Glutathione is an important antioxidant that participates in multiple roles essential for cell survival, such as regulating redox-sensitive proteins and protecting from oxidative and xenobiotic stressors. GSH deficiency renders cells vulnerable to injury and has been associated with several ocular disorders, including AMD, glaucoma, and diabetic retinopathy. GSH is produced in the cytosol and transported into organelles (nucleus, endoplasmic reticulum and mitochondria) via specialized transporters. Two novel GSH transporters recently characterized for the mitochondria were functionally linked to regulation of mitochondrial respiration, thereby providing evidence for the critical role of GSH in maintaining mitochondrial function. Augmentation of the mitochondrial GSH pool through upregulation or activation of these GSH transporters could provide a valuable approach to preventing retinal diseases linked to mitochondrial dysfunction.

\section{Future Directions}

While the SLC25 protein family has been known for many years, the participation of SLC25A10 (DIC) and SLC25A11 (OGC) in the transport of GSH into the mitochondria is a recent finding; therefore, the significance will need further investigation. Some salient points related to this finding that may trigger future research are summarized below.

Only $50-60 \%$ of GSH transport to mitochondria is accounted for by the two transporter proteins, suggesting the existence of other undescribed carriers for GSH.

Both OGC and DIC transport multiple substrates and perform other functions. For example, DIC participates in fatty acid synthesis [93] and OGC in insulin secretion [109]. 
Other upstream Kreb's intermediate carriers may regulate mGSH and its carriers. Recently, when the mitochondrial pyruvate carrier (MPC), which transports pyruvate from the cytosol into the mitochondrial matrix $[110,111]$, was knocked out, total GSH was found to be $50 \%$ lower in the $\mathrm{KO}$ retina [112]. Furthermore, retina-specific deletion of MPC1 resulted in progressive retinal degeneration and decline of visual function in photoreceptors [112]. It is to be noted that loss of MPC1 blocks the entry of pyruvate into mitochondria and depletes $\alpha$-ketoglutarate, a precursor for the synthesis of glutamate, glutamine, and GSH [113].

Analogs and prodrugs are employed for the delivery of GSH because of its poor stability and poor bioavailability [114]. For example, N-acetyl-L-cysteine (a prodrug of L-cysteine) significantly increased GSH levels in RPE in vitro [59]. It would be of interest to study whether this prodrug will be applicable to prevent retinal degeneration in animal models, specifically those that exhibit elevated oxidative stress in the RPE monolayer (for example, in Sod2 knockout mice [115]). Whether the prodrug selectively upregulates mGSH or its carriers will be worthy of investigation.

Mitochondrial-targeting agents based on peptides possess remarkable advantages and can augment GSH in GSH-deficient conditions. For example, a dendrimer-drug construct (TPP-D-NAC) with triphenyl phosphonium (TPP) for mitochondrial targeting of NAC was shown recently to offer protection in a brain injury model [116]. Such an approach can also be utilized for upregulating mGSH with endogenous and mitochondrial-derived peptides $[49,81,117]$. For example, we have shown that incubation of RPE cells with a mitochondria-derived peptide, humanin, significantly upregulated mGSH [117].

Finally, studies on how changes in the mGSH status will regulate key events related to mitochondrial dysfunction, such as autophagy/mitophagy and inflammation, will be fruitful to pursue.

Author Contributions: P.G.S. and R.K. conceptualized and wrote the initial draft. P.G.S., R.K. and D.A.F. prepared the revised draft and edited the final version of the MS. All authors have read and agreed to the published version of the manuscript.

Funding: This work was supported by the National Institutes of Health (grant number R01 EY30141 (RK)), the Ryan Initiative for Macular Research (RIMR), and a gift from KECK Foundation to Doheny Eye Institute. DAF was supported by the NIH (R01 EY026012 and R01 EY028554), the Elaine and Robert Larson Endowed Vision Research Chair, the Lindsay Family Foundation, and an anonymous benefactor for AMD research.

Institutional Review Board Statement: RPE primary cultures (used in Figure 3) were developed from RPE harvested from de-identified donor eyes obtained from the Lions Gift of Sight (St. Paul, MN). The Lions Gift of Sight is licensed by the Eye Bank Association of America (accreditation \#0015204) and accredited by the Food and Drug Association of America (accreditation 3000718538). Donor tissue is considered pathological specimens and is therefore exempt from the process of Institutional Board Approval. The primary RPE cells (used in Figures 4 and 6) were isolated from human fetal eyes obtained from Advanced Bioscience Resources Inc. (Alameda, CA, USA) and Novogenix Laboratories, LLC (Los Angeles, CA, USA). The study was conducted according to the guidelines of the Declaration of Helsinki, and approved by the Institutional Review Board of UCLA/Doheny Eye Institute.

Informed Consent Statement: Human donor eyes (used in Figure 3) were obtained with written informed consent of the donor or donor's family for use in medical research in accordance with the Declaration of Helsinki.

Conflicts of Interest: D.A.F. is a member of the Scientific Advisor Board for Vinci Pharmaceuticals, Inc. R.K. and P.G.S. declare no conflict of interest. The funders had no role in the design of the study; in the collection, analyses, or interpretation of data; in the writing of the manuscript, or in the decision to publish the results. 


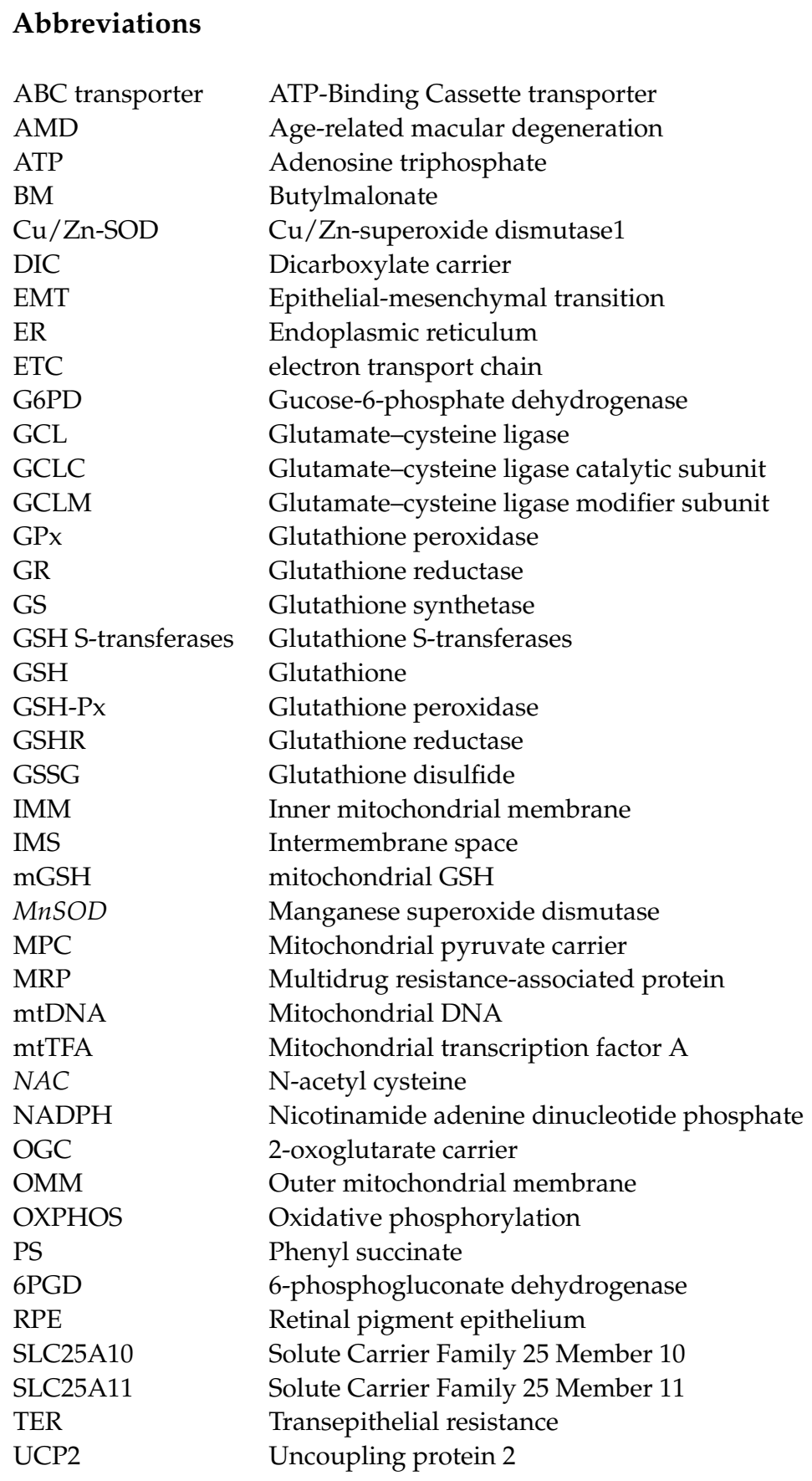

\section{References}

1. Sreekumar, P.G.; Spee, C.; Ryan, S.J.; Cole, S.P.C.; Kannan, R.; Hinton, D.R. Mechanism of RPE Cell Death in $\alpha$-Crystallin Deficient Mice: A Novel and Critical Role for MRP1-Mediated GSH Efflux. PLoS ONE 2012, 7, e33420. [CrossRef]

2. Kwon, D.H.; Lee, H.; Park, C.; Hong, S.-H.; Hong, S.H.; Kim, G.-Y.; Cha, H.-J.; Kim, S.; Kim, H.-S.; Hwang, H.-J.; et al. Glutathione Induced Immune-Stimulatory Activity by Promoting M1-Like Macrophages Polarization via Potential ROS Scavenging Capacity. Antioxidants 2019, 8, 413. [CrossRef]

3. Sinha, R.; Sinha, I.; Calcagnotto, A.; Trushin, N.; Haley, J.S.; Schell, T.D.; Richie, J.P. Oral supplementation with liposomal glutathione elevates body stores of glutathione and markers of immune function. Eur. J. Clin. Nutr. 2018, 72, 105-111. [CrossRef]

4. Liu, R.M. Gaston Pravia KA: Oxidative stress and glutathione in TGF-beta-mediated fibrogenesis. Free Radic. Biol. Med. 2010, 48, 1-15. [CrossRef] [PubMed]

5. Ballatori, N.; Krance, S.M.; Marchan, R.; Hammond, C.L. Plasma membrane glutathione transporters and their roles in cell physiology and pathophysiology. Mol. Asp. Med. 2009, 30, 13-28. [CrossRef] [PubMed]

6. Aquilano, K.; Baldelli, S.; Ciriolo, M.R. Glutathione: New roles in redox signaling for an old antioxidant. Front. Pharmacol. 2014, 5, 196. [CrossRef] [PubMed] 
7. Yuan, L.; Kaplowitz, N. Glutathione in liver diseases and hepatotoxicity. Mol. Asp. Med. 2009, 30, 29-41. [CrossRef]

8. Vivancos, P.D.; Wolff, T.; Markovic, J.; Pallardó, F.V.; Foyer, C.H. A nuclear glutathione cycle within the cell cycle. Biochem. J. 2010, 431, 169-178. [CrossRef]

9. Franco, R.; Cidlowski, J.A. Glutathione Efflux and Cell Death. Antioxid. Redox Signal. 2012, 17, 1694-1713. [CrossRef]

10. DePonte, M. The Incomplete Glutathione Puzzle: Just Guessing at Numbers and Figures? Antioxid. Redox Signal. 2017, 27, 11301161. [CrossRef]

11. Kumar, C.; Igbaria, A.; D'Autreaux, B.; Planson, A.-G.; Junot, C.; Godat, E.; Bachhawat, A.K.; Delaunay-Moisan, A.; Toledano, M.B. Glutathione revisited: A vital function in iron metabolism and ancillary role in thiol-redox control. EMBO J. 2011, 30, $2044-2056$. [CrossRef]

12. Bass, R.; Ruddock, L.W.; Klappa, P.; Freedman, R.B. A Major Fraction of Endoplasmic Reticulum-located Glutathione Is Present as Mixed Disulfides with Protein. J. Biol. Chem. 2004, 279, 5257-5262. [CrossRef]

13. Schafer, F.Q.; Buettner, G.R. Redox environment of the cell as viewed through the redox state of the glutathione disulfide/glutathione couple. Free. Radic. Biol. Med. 2001, 30, 1191-1212. [CrossRef]

14. Lu, S.C. Glutathione synthesis. Biochim. Biophys. Acta (BBA) Gen. Subj. 2013, 1830, 3143-3153. [CrossRef]

15. Meister, A.; Anderson, M.E. Glutathione. Annu. Rev. Biochem. 1983, 52, 711-760. [CrossRef] [PubMed]

16. McConnachie, L.A.; Mohar, I.; Hudson, F.N.; Ware, C.B.; Ladiges, W.C.; Fernandez, C.; Chatterton-Kirchmeier, S.; White, C.C.; Pierce, R.H.; Kavanagh, T.J. Glutamate Cysteine Ligase Modifier Subunit Deficiency and Gender as Determinants of Acetaminophen-Induced Hepatotoxicity in Mice. Toxicol. Sci. 2007, 99, 628-636. [CrossRef]

17. Dalton, T.P.; Dieter, M.Z.; Yang, Y.; Shertzer, H.G.; Nebert, D.W. Knockout of the Mouse Glutamate Cysteine Ligase Catalytic Subunit (Gclc) Gene: Embryonic Lethal When Homozygous, and Proposed Model for Moderate Glutathione Deficiency When Heterozygous. Biochem. Biophys. Res. Commun. 2000, 279, 324-329. [CrossRef] [PubMed]

18. Franklin, C.C.; Backos, D.S.; Mohar, I.; White, C.C.; Forman, H.J.; Kavanagh, T.J. Structure, function, and post-translational regulation of the catalytic and modifier subunits of glutamate cysteine ligase. Mol. Asp. Med. 2009, 30, 86-98. [CrossRef]

19. Bachhawat, A.K.; Yadav, S. The glutathione cycle: Glutathione metabolism beyond the gamma-glutamyl cycle. IUBMB Life 2018, 70, 585-592. [CrossRef]

20. Crawford, R.R.; Prescott, E.T.; Sylvester, C.F.; Higdon, A.N.; Shan, J.; Kilberg, M.S.; Mungrue, I.N. Human CHAC1 Protein Degrades Glutathione, and mRNA Induction Is Regulated by the Transcription Factors ATF4 and ATF3 and a Bipartite ATF/CRE Regulatory Element. J. Biol. Chem. 2015, 290, 15878-15891. [CrossRef]

21. Ferrington, D.A.; Ebeling, M.C.; Kapphahn, R.J.; Terluk, M.R.; Fisher, C.R.; Polanco, J.R.; Roehrich, H.; Leary, M.M.; Geng, Z.; Dutton, J.R.; et al. Altered bioenergetics and enhanced resistance to oxidative stress in human retinal pigment epithelial cells from donors with age-related macular degeneration. Redox Biol. 2017, 13, 255-265. [CrossRef]

22. Gherghel, D.; Griffiths, H.R.; Hilton, E.J.; Cunliffe, I.A.; Hosking, S.L. Systemic Reduction in Glutathione Levels Occurs in Patients with Primary Open-Angle Glaucoma. Investig. Opthalmol. Vis. Sci. 2005, 46, 877-883. [CrossRef]

23. Perricone, C.; De Carolis, C.; Perricone, R. Glutathione: A key player in autoimmunity. Autoimmun. Rev. 2009, 8, 697-701. [CrossRef]

24. Qin, L.; Mroczkowska, S.A.; Ekart, A.; Patel, S.R.; Gibson, J.M.; Gherghel, D. Patients with early age-related macular degeneration exhibit signs of macro- and micro-vascular disease and abnormal blood glutathione levels. Graefe's Arch. Clin. Exp. Ophthalmol. 2014, 252, 23-30. [CrossRef] [PubMed]

25. Floreani, M.; Napoli, E.; Martinuzzi, A.; Pantano, G.; De Riva, V.; Trevisan, R.; Bisetto, E.; Valente, L.; Carelli, V.; Dabbeni-Sala, F. Antioxidant defences in cybrids harboring mtDNA mutations associated with Leber's hereditary optic neuropathy. FEBS J. 2005, 272, 1124-1135. [CrossRef]

26. Ghelli, A.; Porcelli, A.M.; Zanna, C.; Martinuzzi, A.; Carelli, V.; Rugolo, M. Protection against Oxidant-Induced Apoptosis by Exogenous Glutathione in Leber Hereditary Optic Neuropathy Cybrids. Investig. Opthalmol. Vis. Sci. 2008, 49, 671-676. [CrossRef] [PubMed]

27. Lutchmansingh, F.K.; Hsu, J.W.; Bennett, F.I.; Badaloo, A.V.; McFarlane-Anderson, N.; Gordon-Strachan, G.M.; Wright-Pascoe, R.A.; Jahoor, F.; Boyne, M.S. Glutathione metabolism in type 2 diabetes and its relationship with microvascular complications and glycemia. PLoS ONE 2018, 13, e0198626. [CrossRef]

28. Hyttinen, J.M.T.; Kannan, R.; Felszeghy, S.; Niittykoski, M.; Salminen, A.; Kaarniranta, K. The Regulation of NFE2L2 (NRF2) Signalling and Epithelial-to-Mesenchymal Transition in Age-Related Macular Degeneration Pathology. Int. J. Mol. Sci. 2019, 20, 5800. [CrossRef] [PubMed]

29. Mamuya, F.A.; Wang, Y.; Roop, V.H.; Scheiblin, D.A.; Zajac, J.C.; Duncan, M.K. The roles of $\alpha$ V integrins in lens EMT and posterior capsular opacification. J. Cell. Mol. Med. 2014, 18, 656-670. [CrossRef]

30. Wei, Z.; Caty, J.; Whitson, J.; Zhang, A.D.; Srinivasagan, R.; Kavanagh, T.J.; Yan, H.; Fan, X. Reduced Glutathione Level Promotes Epithelial-Mesenchymal Transition in Lens Epithelial Cells via a Wnt/beta-Catenin-Mediated Pathway: Relevance for Cataract Therapy. Am. J. Pathol. 2017, 187, 2399-2412. [CrossRef] [PubMed]

31. Zhang, J.; Zhang, W.; Zhang, T.; Zhou, Q.; Liu, J.; Liu, Y.; Kong, D.; Yu, W.; Liu, R.; Hai, C. TGF-beta1 induces epithelial-tomesenchymal transition via inhibiting mitochondrial functions in A549 cells. Free Radic. Res. 2018, 52, 1432-1444. [CrossRef] [PubMed] 
32. Priglinger, C.S.; Obermann, J.; Szober, C.M.; Merl-Pham, J.; Ohmayer, U.; Behler, J.; Gruhn, F.; Kreutzer, T.C.; Wertheimer, C.; Geerlof, A.; et al. Epithelial-to-Mesenchymal Transition of RPE Cells In Vitro Confers Increased beta1,6-N-Glycosylation and Increased Susceptibility to Galectin-3 Binding. PLoS ONE 2016, 11, e0146887. [CrossRef] [PubMed]

33. Ames, A., 3rd; Li, Y.Y.; Heher, E.C.; Kimble, C.R. Energy metabolism of rabbit retina as related to function: High cost of Na+ transport. J. Neurosci. 1992, 12, 840-853. [CrossRef]

34. Joyal, J.-S.; Gantner, M.L.; Smith, L.E. Retinal energy demands control vascular supply of the retina in development and disease: The role of neuronal lipid and glucose metabolism. Prog. Retin. Eye Res. 2018, 64, 131-156. [CrossRef]

35. Hsu, S.; Molday, R. Glucose metabolism in photoreceptor outer segments. Its role in phototransduction and in NADPH-requiring reactions. J. Biol. Chem. 1994, 269, 17954-17959. [CrossRef]

36. Lu, S.C.; Bao, Y.; Huang, Z.Z.; Sarthy, V.P.; Kannan, R. Regulation of gamma-glutamylcysteine synthetase subunit gene expression in retinal Müller cells by oxidative stress. Investig. Ophthalmol. Vis. Sci. 1999, 40, 1776-1782.

37. Jiang, S.; Moriarty, S.E.; Grossniklaus, H.; Nelson, K.C.; Jones, D.P.; Sternberg, P. Increased oxidant-induced apoptosis in cultured nondividing human retinal pigment epithelial cells. Investig. Ophthalmol. Vis. Sci. 2002, 43, 2546-2553.

38. Marc, R.E.; Jones, B.; Watt, C.; Vazquez-Chona, F.; Vaughan, D.; Organisciak, D. Extreme retinal remodeling triggered by light damage: Implications for age related macular degeneration. Mol. Vis. 2008, 14, 782-805. [PubMed]

39. Guo, X.; Jiang, Q.; Tuccitto, A.; Chan, D.; Alqawlaq, S.; Won, G.-J.; Sivak, J.M. The AMPK-PGC-1 $\alpha$ signaling axis regulates the astrocyte glutathione system to protect against oxidative and metabolic injury. Neurobiol. Dis. 2018, 113, 59-69. [CrossRef] [PubMed]

40. Huster, D.; Hjelle, O.P.; Haug, F.M.; Nagelhus, E.A.; Reichelt, W.; Ottersen, O.P. Subcellular compartmentation of glutathione and glutathione precursors. A high resolution immunogold analysis of the outer retina of guinea pig. Anat. Embryol. 1998, 198, 277-287. [CrossRef]

41. Schütte, M.; Werner, P. Redistribution of glutathione in the ischemic rat retina. Neurosci. Lett. 1998, 246, 53-56. [CrossRef]

42. Carter-Dawson, L.; Shen, F.F.; Harwerth, R.S.; Crawford, M.L.; Smith, E.L., 3rd; Whitetree, A. Glutathione content is altered in Muller cells of monkey eyes with experimental glaucoma. Neurosci. Lett. 2004, 364, 7-10. [CrossRef]

43. Roh, Y.-J.; Moon, C.; Kim, S.Y.; Park, M.H.; Bae, Y.C.; Chun, M.-H.; Moon, J.-I. Glutathione depletion induces differential apoptosis in cells of mouse retina, in vivo. Neurosci. Lett. 2007, 417, 266-270. [CrossRef] [PubMed]

44. Porosk, R.; Kilk, K.; Mahlapuu, R.; Terasmaa, A.; Soomets, U. Glutathione system in Wolfram syndrome 1-deficient mice. Mol. Med. Rep. 2017, 16, 7092-7097. [CrossRef]

45. Wiley, S.E.; Andreyev, A.Y.; Divakaruni, A.S.; Karisch, R.; Perkins, G.; Wall, E.A.; Van Der Geer, P.; Chen, Y.; Tsai, T.; Simon, M.I.; et al. Wolfram Syndrome protein, Miner1, regulates sulphydryl redox status, the unfolded protein response, and Ca 2+ homeostasis. EMBO Mol. Med. 2013, 5, 904-918. [CrossRef]

46. Bharathselvi, M.; Biswas, S.; Raman, R.; Selvi, R.; Coral, K.; Narayanansamy, A.; Ramakrishnan, S.; Sulochana, K.N. Homocysteine \& its metabolite homocysteine-thiolactone \& deficiency of copper in patients with age related macular degeneration-A pilot study. Indian J. Med. Res. 2016, 143, 756. [CrossRef]

47. Coral, K.; Raman, R.; Rathi, S.; Rajesh, M.; Sulochana, K.N.; Angayarkanni, N.; Paul, P.G.; Ramakrishnan, S. Plasma homocysteine and total thiol content in patients with exudative age-related macular degeneration. Eye 2005, 20, 203-207. [CrossRef]

48. Javadzadeh, A.; Ghorbanihaghjo, A.; Bahreini, E.; Rashtchizadeh, N.; Argani, H.; Alizadeh, S. Plasma oxidized LDL and thiol-containing molecules in patients with exudative age-related macular degeneration. Mol. Vis. 2010, 16, 2578-2584. [PubMed]

49. Dou, G.; Sreekumar, P.G.; Spee, C.; He, S.; Ryan, S.J.; Kannan, R.; Hinton, D.R. Deficiency of $\alpha$ B crystallin augments ER stress-induced apoptosis by enhancing mitochondrial dysfunction. Free Radic. Biol. Med. 2012, 53, 1111-1122. [CrossRef] [PubMed]

50. Sun, Y.; Zheng, Y.; Wang, C.; Liu, Y. Glutathione depletion induces ferroptosis, autophagy, and premature cell senescence in retinal pigment epithelial cells. Cell Death Dis. 2018, 9, 1-15. [CrossRef] [PubMed]

51. Terluk, M.R.; Ebeling, M.C.; Fisher, C.R.; Kapphahn, R.J.; Yuan, C.; Kartha, R.V.; Montezuma, S.R.; Ferrington, D.A. N-AcetylL-cysteine Protects Human Retinal Pigment Epithelial Cells from Oxidative Damage: Implications for Age-Related Macular Degeneration. Oxidative Med. Cell. Longev. 2019, 2019, 5174957. [CrossRef] [PubMed]

52. Ebeling, M.C.; Polanco, J.R.; Qu, J.; Tu, C.; Montezuma, S.R.; Ferrington, D.A. Improving retinal mitochondrial function as a treatment for age-related macular degeneration. Redox Biol. 2020, 34, 101552. [CrossRef]

53. Mitter, S.K.; Song, C.; Qi, X.; Mao, H.; Rao, H.; Akin, D.; Lewin, A.; Grant, M.; Dunn, W.; Ding, J.; et al. Dysregulated autophagy in the RPE is associated with increased susceptibility to oxidative stress and AMD. Autophagy 2014, 10, 1989-2005. [CrossRef] [PubMed]

54. Tosi, G.M.; Giustarini, D.; Franci, L.; Minetti, A.; Imperatore, F.; Caldi, E.; Fiorenzani, P.; Aloisi, A.M.; Sparatore, A.; Rossi, R.; et al. Superior Properties of N-acetylcysteine Ethyl Ester over N-Acetyl Cysteine to Prevent Retinal Pigment Epithelial Cells Oxidative Damage. Int. J. Mol. Sci. 2021, 22, 600. [CrossRef]

55. Lee, J.-J.; Ishihara, K.; Notomi, S.; Efstathiou, N.E.; Ueta, T.; Maidana, D.; Chen, X.; Iesato, Y.; Caligiana, A.; Vavvas, D.G. Lysosome-associated membrane protein-2 deficiency increases the risk of reactive oxygen species-induced ferroptosis in retinal pigment epithelial cells. Biochem. Biophys. Res. Commun. 2020, 521, 414-419. [CrossRef] [PubMed]

56. Totsuka, K.; Ueta, T.; Uchida, T.; Roggia, M.F.; Nakagawa, S.; Vavvas, D.G.; Honjo, M.; Aihara, M. Oxidative stress induces ferroptotic cell death in retinal pigment epithelial cells. Exp. Eye Res. 2019, 181, 316-324. [CrossRef] 
57. Bertram, K.M.; Baglole, C.J.; Phipps, R.P.; Libby, R.T. Molecular regulation of cigarette smoke induced-oxidative stress in human retinal pigment epithelial cells: Implications for age-related macular degeneration. Am. J. Physiol. Physiol. 2009, 297, C1200-C1210. [CrossRef]

58. Alhasani, R.H.; Almarhoun, M.; Zhou, X.; Reilly, J.; Patterson, S.; Zeng, Z.; Shu, X. Tauroursodeoxycholic Acid Protects Retinal Pigment Epithelial Cells from Oxidative Injury and Endoplasmic Reticulum Stress In Vitro. Biomedicines 2020, 8, 367. [CrossRef]

59. Kularatne, R.N.; Bulumulla, C.; Catchpole, T.; Takacs, A.; Christie, A.; Stefan, M.C.; Csaky, K.G. Protection of human retinal pigment epithelial cells from oxidative damage using cysteine prodrugs. Free Radic. Biol. Med. 2020, 152, 386-394. [CrossRef]

60. Zhou, J.; Chen, F.; Yan, A.; Xia, X. Madecassoside protects retinal pigment epithelial cells against hydrogen peroxide-induced oxidative stress and apoptosis through the activation of Nrf2/HO-1 pathway. Biosci. Rep. 2020, 40, 40. [CrossRef]

61. Kanwar, M.; Chan, P.-S.; Kern, T.S.; Kowluru, R.A. Oxidative Damage in the Retinal Mitochondria of Diabetic Mice: Possible Protection by Superoxide Dismutase. Investig. Opthalmol. Vis. Sci. 2007, 48, 3805-3811. [CrossRef]

62. Xu, Z.; Wei, Y.; Gong, J.; Cho, H.; Park, J.K.; Sung, E.-R.; Huang, H.; Wu, L.; Eberhart, C.; Handa, J.T.; et al. NRF2 plays a protective role in diabetic retinopathy in mice. Diabetologia 2014, 57, 204-213. [CrossRef] [PubMed]

63. Silva, K.C.; Rosales, M.A.; Biswas, S.K.; De Faria, J.B.L.; De Faria, J.M.L. Diabetic Retinal Neurodegeneration Is Associated With Mitochondrial Oxidative Stress and Is Improved by an Angiotensin Receptor Blocker in a Model Combining Hypertension and Diabetes. Diabetes 2009, 58, 1382-1390. [CrossRef] [PubMed]

64. Gherghel, D.; Mroczkowska, S.; Qin, L. Reduction in Blood Glutathione Levels Occurs Similarly in Patients With Primary-Open Angle or Normal Tension Glaucoma. Investig. Opthalmol. Vis. Sci. 2013, 54, 3333-3339. [CrossRef]

65. Yabana, T.; Sato, K.; Shiga, Y.; Himori, N.; Omodaka, K.; Nakazawa, T. The relationship between glutathione levels in leukocytes and ocular clinical parameters in glaucoma. PLOS ONE 2019, 14, e0227078. [CrossRef]

66. Lee, S.Y.; Usui, S.; Zafar, A.-B.; Oveson, B.C.; Jo, Y.-J.; Lu, L.; Masoudi, S.; Campochiaro, P.A. N-acetylcysteine promotes long-term survival of cones in a model of retinitis pigmentosa. J. Cell. Physiol. 2011, 226, 1843-1849. [CrossRef] [PubMed]

67. Trachsel-Moncho, L.; Benlloch-Navarro, S.; Fernández-Carbonell, Á.; Ramírez-Lamelas, D.T.; Olivar, T.; Silvestre, D.; Poch, E.; Miranda, M. Oxidative stress and autophagy-related changes during retinal degeneration and development. Cell Death Dis. 2018, 9,1-12. [CrossRef]

68. Marí, M.; Morales, A.; Colell, A.; García-Ruiz, C.; Kaplowitz, N.; Fernández-Checa, J.C. Mitochondrial glutathione: Features, regulation and role in disease. Biochim. Biophys. Acta (BBA) Gen. Subj. 2013, 1830, 3317-3328. [CrossRef]

69. Bachhawat, A.K.; Thakur, A.; Kaur, J.; Zulkifli, M. Glutathione transporters. Biochim. Biophys. Acta (BBA) Gen. Subj. 2013, 1830, 3154-3164. [CrossRef]

70. Lash, L.H.; Jones, D.P. Transport of glutathione by renal basal-lateral membrane vesicles. Biochem. Biophys. Res. Commun. 1983, 112, 55-60. [CrossRef]

71. Herzenberg, L.A.; De Rosa, S.C.; Dubs, J.G.; Roederer, M.; Anderson, M.T.; Ela, S.W.; Deresinski, S.C. Glutathione deficiency is associated with impaired survival in HIV disease. Proc. Natl. Acad. Sci. USA 1997, 94, 1967-1972. [CrossRef] [PubMed]

72. Cole, S.P.; Deeley, R.G. Transport of glutathione and glutathione conjugates by MRP1. Trends Pharmacol. Sci. 2006, 27, 438-446. [CrossRef] [PubMed]

73. Van Luyn, M.J.; Muller, M.; Renes, J.; Meijer, C.; Scheper, R.J.; Nienhuis, E.F.; Mulder, N.H.; Jansen, P.L.; De Vries, E.G. Transport of glutathione conjugates into secretory vesicles is mediated by the multidrug-resistance protein 1. Int. J. Cancer 1998, 76, 55-62 [CrossRef]

74. Delic, M.; Mattanovich, D.; Gasser, B. Monitoring intracellular redox conditions in the endoplasmic reticulum of living yeasts. FEMS Microbiol. Lett. 2010, 306, 61-66. [CrossRef]

75. Calabrese, G.; Morgan, B.; Riemer, J. Mitochondrial Glutathione: Regulation and Functions. Antioxid. Redox Signal. 2017, 27, 1162-1177. [CrossRef] [PubMed]

76. Cadenas, E.; Davies, K.J. Mitochondrial free radical generation, oxidative stress, and aging11This article is dedicated to the memory of our dear friend, colleague, and mentor Lars Ernster (1920-1998), in gratitude for all he gave to us. Free Radic. Biol. Med. 2000, 29, 222-230. [CrossRef]

77. Raimundo, N. Mitochondrial pathology: Stress signals from the energy factory. Trends Mol. Med. 2014, 20, 282-292. [CrossRef]

78. Sun, F.; Zhou, Q.; Pang, X.; Xu, Y.; Rao, Z. Revealing various coupling of electron transfer and proton pumping in mitochondrial respiratory chain. Curr. Opin. Struct. Biol. 2013, 23, 526-538. [CrossRef]

79. Venditti, P.; Di Stefano, L.; Di Meo, S. Mitochondrial metabolism of reactive oxygen species. Mitochondrion 2013, 13, 71-82. [CrossRef]

80. Thomas, N.O.; Shay, K.P.; Hagen, T.M. Age-related loss of mitochondrial glutathione exacerbates menadione-induced inhibition of Complex I. Redox Biol. 2019, 22, 101155. [CrossRef]

81. Sreekumar, P.G.; Wang, M.; Spee, C.; Sadda, S.R.; Kannan, R. Transporter-Mediated Mitochondrial GSH Depletion Leading to Mitochondrial Dysfunction and Rescue with $\alpha$ B Crystallin Peptide in RPE Cells. Antioxidants 2020, 9, 411. [CrossRef]

82. Chen, G.; Chen, Z.; Hu, Y.; Huang, P. Inhibition of mitochondrial respiration and rapid depletion of mitochondrial glutathione by beta-phenethyl isothiocyanate: Mechanisms for anti-leukemia activity. Antioxid. Redox Signal. 2011, 15, 2911-2921. [CrossRef]

83. Griffith, O.W.; Meister, A. Origin and turnover of mitochondrial glutathione. Proc. Natl. Acad. Sci. USA 1985, 82, 4668-4672. [CrossRef] 
84. Ribas, V.; Garcia-Ruiz, C.; Fernandez-Checa, J.C. Glutathione and mitochondria. Front. Pharmacol. 2014, 5, 151. [CrossRef] [PubMed]

85. Marí, M.; De Gregorio, E.; De Dios, C.; Roca-Agujetas, V.; Cucarull, B.; Tutusaus, A.; Morales, A.; Colell, A. Mitochondrial Glutathione: Recent Insights and Role in Disease. Antioxidants 2020, 9, 909. [CrossRef]

86. Cummings, B.S.; Angeles, R.; McCauley, R.B.; Lash, L.H. Role of Voltage-Dependent Anion Channels in Glutathione Transport into Yeast Mitochondria. Biochem. Biophys. Res. Commun. 2000, 276, 940-944. [CrossRef] [PubMed]

87. Tatsuta, T.; Scharwey, M.; Langer, T. Mitochondrial lipid trafficking. Trends Cell Biol. 2014, 24, 44-52. [CrossRef] [PubMed]

88. Chen, Z.; Lash, L.H. Evidence for mitochondrial uptake of glutathione by dicarboxylate and 2-oxoglutarate carriers. J. Pharmacol. Exp. Ther. 1998, 285, 608-618. [PubMed]

89. Chen, Z.; Putt, D.A.; Lash, L.H. Enrichment and Functional Reconstitution of Glutathione Transport Activity from Rabbit Kidney Mitochondria: Further Evidence for the Role of the Dicarboxylate and 2-Oxoglutarate Carriers in Mitochondrial Glutathione Transport. Arch. Biochem. Biophys. 2000, 373, 193-202. [CrossRef]

90. Coll, O.; Colell, A.; García-Ruiz, C.; Kaplowitz, N.; Fernández-Checa, J.C. Sensitivity of the 2-oxoglutarate carrier to alcohol intake contributes to mitochondrial glutathione depletion. Hepatology 2003, 38, 692-702. [CrossRef]

91. Wilkins, H.M.; Marquardt, K.; Lash, L.H.; Linseman, D.A. Bcl-2 is a novel interacting partner for the 2-oxoglutarate carrier and a key regulator of mitochondrial glutathione. Free Radic. Biol. Med. 2012, 52, 410-419. [CrossRef]

92. Torres, S.; Matías, N.; Baulies, A.; Nuñez, S.; Alarcon-Vila, C.; Martinez, L.; Nuño, N.; Fernandez, A.; Caballeria, J.; Levade, T.; et al. Mitochondrial GSH replenishment as a potential therapeutic approach for Niemann Pick type C disease. Redox Biol. 2017, 11, 60-72. [CrossRef]

93. Mizuarai, S.; Miki, S.; Araki, H.; Takahashi, K.; Kotani, H. Identification of Dicarboxylate Carrier Slc25a10 as Malate Transporter in de Novo Fatty Acid Synthesis. J. Biol. Chem. 2005, 280, 32434-32441. [CrossRef]

94. Gutiérrez-Aguilar, M.; Baines, C.P. Physiological and pathological roles of mitochondrial SLC25 carriers. Biochem. J. 2013 , 454, 371-386. [CrossRef] [PubMed]

95. Dolce, V.; Cappello, A.R.; Capobianco, L. Mitochondrial tricarboxylate and dicarboxylate-Tricarboxylate carriers: From animals to plants. IUBMB Life 2014, 66, 462-471. [CrossRef] [PubMed]

96. Hamza, I. Intracellular Trafficking of Porphyrins. ACS Chem. Biol. 2006, 1, 627-629. [CrossRef] [PubMed]

97. Wang, M.; Lau, L.-I.; Sreekumar, P.G.; Spee, C.; Hinton, D.R.; Sadda, S.R.; Kannan, R. Characterization and Regulation of Carrier Proteins of Mitochondrial Glutathione Uptake in Human Retinal Pigment Epithelium Cells. Investig. Opthalmol. Vis. Sci. 2019, 60, 500-516. [CrossRef] [PubMed]

98. Sonoda, S.; Spee, C.; Barron, E.; Ryan, S.J.; Kannan, R.; Hinton, D.R. A protocol for the culture and differentiation of highly polarized human retinal pigment epithelial cells. Nat. Protoc. 2009, 4, 662-673. [CrossRef] [PubMed]

99. Zhong, Q.; Putt, D.A.; Xu, F.; Lash, L.H. Hepatic mitochondrial transport of glutathione: Studies in isolated rat liver mitochondria and H4IIE rat hepatoma cells. Arch. Biochem. Biophys. 2008, 474, 119-127. [CrossRef]

100. De Bilbao, F.; Arsenijevic, D.; Vallet, P.; Hjelle, O.P.; Ottersen, O.P.; Bouras, C.; Raffin, Y.; Abou, K.; Langhans, W.; Collins, S.; et al. Resistance to cerebral ischemic injury in UCP2 knockout mice: Evidence for a role of UCP2 as a regulator of mitochondrial glutathione levels. J. Neurochem. 2004, 89, 1283-1292. [CrossRef]

101. Wilkins, H.M.; Brock, S.; Gray, J.J.; Linseman, D.A. Stable over-expression of the 2-oxoglutarate carrier enhances neuronal cell resistance to oxidative stress via Bcl-2-dependent mitochondrial GSH transport. J. Neurochem. 2014, 130, 75-86. [CrossRef]

102. Ratnapriya, R.; Sosina, O.A.; Starostik, M.R.; Kwicklis, M.; Kapphahn, R.J.; Fritsche, L.G.; Walton, A.; Arvanitis, M.; Gieser, L.; Pietraszkiewicz, A.; et al. Retinal transcriptome and eQTL analyses identify genes associated with age-related macular degeneration. Nat. Genet. 2019, 51, 606-610. [CrossRef] [PubMed]

103. Lee, J.-S.; Lee, H.; Lee, S.; Kang, J.H.; Lee, S.-H.; Kim, S.-G.; Cho, E.S.; Kim, N.H.; Yook, J.I.; Kim, S.-Y. Loss of SLC25A11 causes suppression of NSCLC and melanoma tumor formation. EBioMedicine 2019, 40, 184-197. [CrossRef] [PubMed]

104. Zhou, X.; Paredes, J.A.; Krishnan, S.; Curbo, S.; Karlsson, A. The mitochondrial carrier SLC25A10 regulates cancer cell growth. Oncotarget 2015, 6, 9271-9283. [CrossRef] [PubMed]

105. Cheng, Z.; Ristow, M. Mitochondria and Metabolic Homeostasis. Antioxid. Redox Signal. 2013, 19, 240-242. [CrossRef]

106. Sreekumar, P.G.; Ishikawa, K.; Spee, C.; Mehta, H.H.; Wan, J.; Yen, K.; Cohen, P.; Kannan, R.; Hinton, D.R. The MitochondrialDerived Peptide Humanin Protects RPE Cells From Oxidative Stress, Senescence, and Mitochondrial Dysfunction. Investig. Opthalmol. Vis. Sci. 2016, 57, 1238-1253. [CrossRef]

107. Bonawitz, N.D.; Clayton, D.A.; Shadel, G.S. Initiation and Beyond: Multiple Functions of the Human Mitochondrial Transcription Machinery. Mol. Cell 2006, 24, 813-825. [CrossRef]

108. Ikeda, M.; Toshihide, Y.; Fujino, T.; Arai, S.; Saku, K.; Kakino, T.; Tyynismaa, H.; Yamasaki, T.; Yamada, K.-I.; Kang, D.; et al. Overexpression of TFAM or Twinkle Increases mtDNA Copy Number and Facilitates Cardioprotection Associated with Limited Mitochondrial Oxidative Stress. PLoS ONE 2015, 10, e0119687. [CrossRef]

109. Odegaard, M.L.; Joseph, J.W.; Jensen, M.V.; Lu, D.; Ilkayeva, O.; Ronnebaum, S.M.; Becker, T.C.; Newgard, C.B. The Mitochondrial 2-Oxoglutarate Carrier Is Part of a Metabolic Pathway That Mediates Glucose- and Glutamine-stimulated Insulin Secretion. J. Biol. Chem. 2010, 285, 16530-16537. [CrossRef] 
110. Bricker, D.K.; Taylor, E.B.; Schell, J.C.; Orsak, T.; Boutron, A.; Chen, Y.-C.; Cox, J.E.; Cardon, C.M.; Van Vranken, J.G.; Dephoure, N.; et al. A Mitochondrial Pyruvate Carrier Required for Pyruvate Uptake in Yeast, Drosophila, and Humans. Science 2012, 337, 96-100. [CrossRef]

111. Herzig, S.; Raemy, E.; Montessuit, S.; Veuthey, J.-L.; Zamboni, N.; Westermann, B.; Kunji, E.R.S.; Martinou, J.-C. Identification and Functional Expression of the Mitochondrial Pyruvate Carrier. Science 2012, 337, 93-96. [CrossRef] [PubMed]

112. Grenell, A.; Wang, Y.; Yam, M.; Swarup, A.; Dilan, T.L.; Hauer, A.; Linton, J.D.; Philp, N.J.; Gregor, E.; Zhu, S.; et al. Loss of MPC1 reprograms retinal metabolism to impair visual function. Proc. Natl. Acad. Sci. USA 2019, 116, 3530-3535. [CrossRef]

113. Tompkins, S.C.; Sheldon, R.D.; Rauckhorst, A.J.; Noterman, M.F.; Solst, S.R.; Buchanan, J.L.; Mapuskar, K.A.; Pewa, A.D.; Gray, L.R.; Oonthonpan, L.; et al. Disrupting Mitochondrial Pyruvate Uptake Directs Glutamine into the TCA Cycle away from Glutathione Synthesis and Impairs Hepatocellular Tumorigenesis. Cell Rep. 2019, 28, 2608-2619.e6. [CrossRef] [PubMed]

114. Cacciatore, I.; Baldassarre, L.; Fornasari, E.; Mollica, A.; Pinnen, F. Recent Advances in the Treatment of Neurodegenerative Diseases Based on GSH Delivery Systems. Oxidative Med. Cell. Longev. 2012, 2012, 240146. [CrossRef] [PubMed]

115. Brown, E.E.; DeWeerd, A.J.; Ildefonso, C.J.; Lewin, A.S.; Ash, J.D. Mitochondrial oxidative stress in the retinal pigment epithelium (RPE) led to metabolic dysfunction in both the RPE and retinal photoreceptors. Redox Biol. 2019, 24, 101201. [CrossRef]

116. Sharma, A.; Liaw, K.; Sharma, R.; Zhang, Z.; Kannan, S.; Kannan, R.M. Targeting Mitochondrial Dysfunction and Oxidative Stress in Activated Microglia using Dendrimer-Based Therapeutics. Theranostics 2018, 8, 5529-5547. [CrossRef]

117. Matsunaga, D.; Sreekumar, P.G.; Ishikawa, K.; Terasaki, H.; Barron, E.; Cohen, P.; Kannan, R.; Hinton, D.R. Humanin Protects RPE Cells from Endoplasmic Reticulum Stress-Induced Apoptosis by Upregulation of Mitochondrial Glutathione. PLoS ONE 2016, 11, e0165150. [CrossRef] 